\title{
Legal services in North West England: the changing landscape
}

\author{
by David Sugarman
}

$\mathrm{T}$ he five following papers in this issue of Amicus Curiae were selected from a conference on "Legal services in North West England: the changing landscape" hosted by Lancaster University's Centre for Law and Society on September 27, 2007. The conference addressed the current state and future development of the legal profession and legal services in North West England and nationally. It provided the first serious treatment of the legal services revolution in the North West and brought together the key stakeholders for the first time.

The subject-matter was chosen because of its legal, political and local relevance. In the 21 st century, the legal profession and allied legal services are facing significant challenges. They must deal with issues of public accountability, access to justice, commercialisation, competition, diversity and ethics. The debate on these developments has primarily focused on London. The conference was a much-needed move to specifically focus on the challenges and opportunities in North West England. The contemporary relevance of the conference theme was also reflected in the fact that major changes to legal services were currently being discussed in the context of the Government's Legal Services Bill (which received Royal Assent on October 30, 2007), which will transform the provision and regulation of legal services.

The conference theme was also chosen because of its interdisciplinarity. A deliberate effort was made to involve a wide range of colleagues within Lancaster University with an interest in legal services as well as individuals representing the principal stakeholders. The Conference formed a part of Lancaster University's Institute of Advanced Studies Annual Research Programme 2006-7 on "Regions and Regionalism in and beyond Europe" and enjoyed strong support in Law, Geography and the Management School. University-wide support was underpinned by the involvement of Lancaster's ViceChancellor, Professor Paul Wellings, who opened the proceedings. The Conference also achieved a national profile through its co-sponsorship by the Institute of Advanced Legal Studies, University of London, and through the involvement of leading national figures and organisations in the field.

Over 80 delegates attended the conference, making it the largest event of its kind organised under the auspices of the Lancaster University Law School. The delegates included senior representatives from:

- the Ministry of Justice

- the Office of the Legal Services Complaints Commissioner and Legal Services Ombudsman for England and Wales

- the local judiciary

- the North West Development Agency

- local/regional legal practitioners (from the biggest to the smallest law firms in the North West)

- Cumbria Community Legal Services

- the Law Centres Federation

- ProfessionalLiverpool

- Pro Manchester

- the Citizens Advice Service

- the Legal Action Group

- The Law Society of England and Wales

- the Association of Personal Injury Lawyers

- the Institute of Legal Executives

- LawWorks (the principal national pro bono organisation)

- Shelter Cumbria

Additionally, academics from several universities were in attendance, as were representatives of the Lancaster University Law Students Society and student members of the "Innocence" Project. The managing partners of several of largest law firms in the North West, including Grahame Codd (Irwin Mitchell) and Andrew Leaitherland (DWF) also attended. 
Many people helped to make the conference a resounding success. I would like especially to thank the speakers at the conference; Dr James Faulconbridge (Geography, Lancaster University), Georgina Firth (Law, Lancaster University) and Dr Daniel Muzio (Leeds University Business School) for their assistance with the organisation of the conference; Professor Bob Jessop (Director, Institute of Advanced Studies), Professor Geraint Howells (Law), Professor David Milman (Law) and Dr Robert Crawshaw (Director, Annual Research Programme 2006-7 on "Regions and Regionalism in and beyond Europe") for backing the conference; and Angela Turner, Anne-Marie Mumford and Helen Caton, who provided valuable administrative support. The Institute of Advanced Legal Studies, University of London, was a vital partner in the organisation of the conference, and I would like to thank its Director, Professor Avrom Sherr, for his commitment to sustain legal scholarship, and academic-practitioner relations beyond London and the Home Counties.

The papers published here are largely in the form that they were presented in September 2007.

Professor David Sugarman

Director, Centre for Law and Society Lancaster University Law School

\title{
Lawyers and legal services in North West England
}

\author{
by David Sugarman
}

$\mathrm{T}$ he diversity and fragmentation that tends to characterise contemporary legal practice is demonstrated within the North West.

One of the factors that makes the North West distinctive is its geographical, cultural and economic diversity and the way this is reflected in the character of its legal services. The North West is the second largest legal centre in the UK, with around 1800 legal service companies in the region. But such figures conceal a legal services industry and market that is highly fragmented, segmented, variegated and multi-layered.

The north of the region is largely rural, and characterised by some of the smallest legal practices and voluntary legal advice centres in England and Wales (Cf K Economides and M Blacksell (1987). "Access to Justice in Rural Britain: Final Report," Anglo-American Law Review 16). Current Law Society statistics show that of the 1133 firms of solicitors in the North West - defined as covering Cumbria, Lancashire, Cheshire, Manchester and Merseyside - 38.9 per cent are solo practitioners and another 44 per cent have fewer than five partners.

At the southern end of the region, two large urban conurbations centred on the cities of Manchester and
Liverpool are dominant. In terms of ethnicity, cities like Manchester and Liverpool, and towns such as Blackburn, are amongst the most diverse in Europe. And it is Manchester and Liverpool, along with Preston, that have seen the largest increase in the number, size and turnover of legal practices - sustained in part by mergers with niche firms, diversification and creating new departments. These firms may not have the muscle to take over and form partnerships in other countries in the way that London's magic circle firms are able to, but the larger regional firms undertake substantial domestic deals for PLC's.

As Manchester and Liverpool have attracted an increasing number of high-value clients, so the business end of the legal profession has generally flourished within and beyond the large conurbations. This would be true of firms such as DWF, Irwin Mitchell and Pannone's - all of which were represented at the September 2007 conference. Notable innovation includes the efforts of the Manchester based Co-operative Insurance to develop a quality legal advice and assistance business with an outreach that extends beyond the usual private client base. Moreover local and regional legal practices have proved themselves adept at developing and responding to the volume services market 